\title{
Den store strid om islam
}

Debat mellem Martin Krasnik og Jakob Skovgaard-Petersen

At der er krig og kaos i Mellemøsten er kun alt for tydeligt. Men er islam - regionens dominerende religion - $i$ sig selv et problem, eller handler det om andre ting, når Mellemøsten står i flammer, og islamiske terrorister hærger Vesten? Det har Weekendavisens chefredaktør Martin Krasnik og professor på Københavns Universitet Jakob Skovgaard-Petersen stredes om de seneste måneder.

Startskuddet var Martin Krasniks leder 'Ufredens religion', der blev offentliggjort i Weekendavisen den 9. juni. Udenrigs har faet lov optrykke de oprindelige indlæg samt fået de to debattører til at skrive sammen om islam og dens problemer.

Første akt: Ufredens religion

(Ledende artikel $i$ Weekendavisen den 9. juni 2017)

Mindre end to uger efter terrorangrebet på børn og unge mennesker i Manchester skete det igen: Tre muslimer dræbte og lemlæstede tilfældige mennesker i London. Hvis der ikke har været nye angreb efter denne avis' deadline torsdag eftermiddag, har der i år hidtil været ni terrorangreb udført af muslimer i Vesteuropa.

Sidste år var tallet 24 . Læg dertil angre- bene i Tyrkiet og Rusland, som får listen over ofre for religiøs terror til at vokse markant. Tilføjer man religiøst motiverede angreb på civile i Mellemøsten, bliver optællingen helt uoverskuelig. Lad os blot nævne disse uhyrligheder: I denne uge slog jihadister, muligvis fra Islamisk Stat, 12 mennesker ihjel i Iran. I Kabul i sidste uge blev 150 dræbt af en bilbombe, de fleste civile, deriblandt mange børn. Dertil kommer hyppige angreb på den koptiske minoritet i Egypten og massakrer på civile - oftest shiamuslimer - i Irak. I Pakistan forfølges og angribes kvinder, kristne, frafaldne, homoseksuelle og andre minoriteter for at bryde islamiske regler og love. I Saudi-Arabien gennemsyrer det hele samfundet. I afrikanske lande angribes civile af islamistiske grupperinger. Og i fjernere dele af den muslimske verden føres religiøs krig med velkendte mål og midler.

Religion er et emne, vi har svært ved at diskutere. Sund fornuft og dømmekraft kortsluttes, forstand fortrænges af ønsketænkning. For eksempel har der i årenes løb bredt sig den mærkværdige opfattelse, at islam er 'fredens religion'. Sådan har det lydt fra alskens vestlige politikere, fra religiøse muslimske ledere, og ikke mindst fra de mange millioner og atter millio-

Martin Krasnik er chefredaktør på Weekendavisen og Jakob SkovgaardPetersen er professor på Københavns Universitet. 


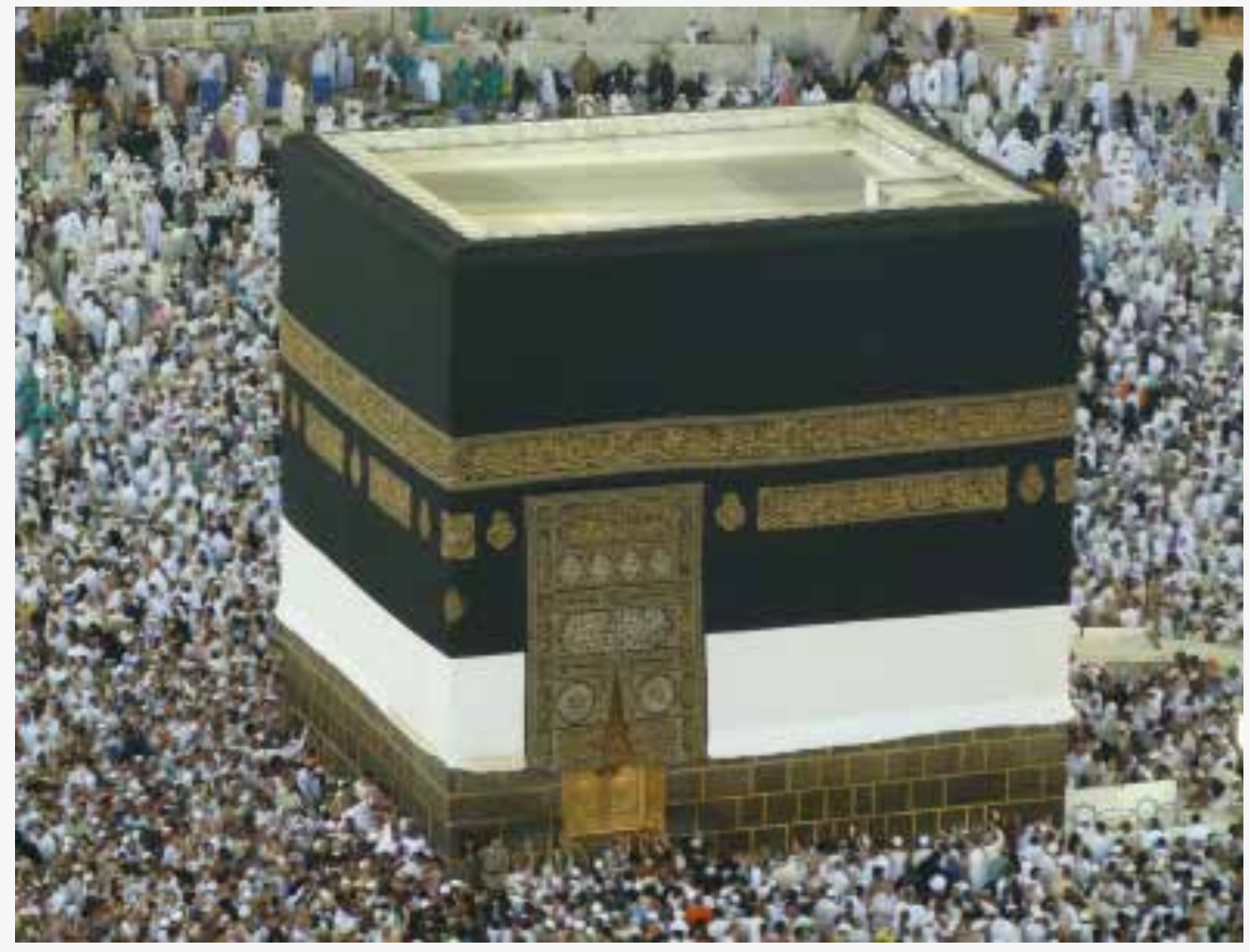

FOTO: Tab59 via Wikimedia Commons

Kabaen i Masjid el Haram, Mekka, 2010 
ner muslimer, der blot vil leve i ro og fred med deres religion. Jo oftere uskyldige civile dræbes med henvisning til islam, islamiske dogmer og islamiske tekster, desto mere afvises det, at religionen har noget med sagen at gøre.

Er islam virkelig fredens religion, må der være noget, det meste af den muslimske verden har misforstået.

Her råder nemlig ufred overalt. De fleste muslimsk dominerede stater holdes i et religiøst jerngreb, hærges af religiøs vold, social tvang og ufrihed; elendigheder, der også præger store dele af det muslimske mindretal i Europa.

Der bruges uanede mængder af energi på at finde forklaringer: social armod, kriminalitet, kolonitidens arv, vestlig udenrigspolitik. Men der bruges meget lidt tid på at finde svaret dér, hvor volden selv henter sin legitimitet.

Godt vil det derfor være at tale klart: Terroristerne har ikke svært ved at retfærdiggøre deres handlinger med islam. Ofte bortforklares det med, at alle religioner $\mathrm{da}$ har potentiale for ekstreme fortolkninger. Og ja, der er ingen tvivl om, at de tre monoteistiske religioner alle leverer rigeligt gods til voldsparate mennesker. Påstanden om at indehave en ufejlbarlig tekst og besidde en universel sandhed, der ekskluderer alle andre end de rettroende, er i sig selv uegnet til fredelig sameksistens.

Kristendommen har ufattelige lidelser på samvittigheden: med kravet om at udbrede den sande lære til alverden fulgte ofte slaveri, undertvingelse og etniske udrensninger. At sætte spørgsmålstegn ved det kristne monopol på magt, viden og moral blev straffet med døden. Den romerskkatolske kirke er skyld i ufattelige lidelser, ligesom de protestantiske aflægninger har stor elendighed på samvittigheden.
Jødedommen, der som islam er en lovreligion, har det uhyggeligt svært med minoriteter og anderledes tænkende, og i Israel undergraver religiøse grupper konsekvent demokrati og retsstat. Når religiøse jøder får politisk magt, følger ikke fred og kompromis, tværtimod. Det samme kan man sige om islam - hér er det blot endnu værre. Der er ikke et eneste muslimsk land, man ville have lyst til at bo i, hvis man ønsker at leve frit endsige udfolde sin kritiske sans offentligt.

Mindre ønsketænkning er nødvendig. Det vil være en hård opgave at forvandle islam til en fredens religion. Islam påstår at have svar på alle livets spørgsmål og hele samfundets indretning. Islam mener ikke blot at indehave sandheden, men den endelige åbenbaring og det endda givet $\mathrm{i}$ en ufejlbarlig tekst til et ufejlbarligt menneske. Angreb på dogmerne er et angreb på denne totalitære, endegyldige sandhed. Det fører ikke til fredelig sameksistens. At undertrykkelse af kvinder, vantro og frafaldne er en del af denne ufravigelige sandhed fører ikke til fredelig sameksistens. Forherligelse af krig, undertvingelse af fjender og den absolutte tro på, at verden går under med én sand sejrherre stående tilbage - det fører heller ikke til fredelig sameksistens.

Islam er mere ufredelig end de to andre monoteistiske religioner. Det forklarer ikke alene, hvorfor markant færre jøder og kristne går og myrder deres medborgere i religionens navn eller henholder sig til de samme dogmer som voldsmænd. Det skyldes, lyder det ofte, at jødedom og kristendom har gennemlevet hver sin reformation, så der i dag findes stærkt troende reformerte og konservative jøder og kristne, der for længst er holdt op med at tage deres religions dogmer og tekster bogstaveligt. Det afgørende er dog, at den vestli- 
ge verden har udsat sig selv for flere hundrede års sekularisering og oplysning, hvor det religiøse monopol på moralsk, kulturel og politisk magt ét for ét er faldet. Denne sekularisering har været helt fraværende eller meget overfladisk i den muslimske verden.

Er islam ikke en fredelig religion, må man stille spørgsmålet: Kan den blive det? Måske - hvis muslimer helt grundlæggende forandrer deres religion.

Den såkaldt ekstreme udgave af islam er desværre en ganske plausibel fortolkning af teksterne, og er man religiøs muslim, er det nærmest umuligt at finde institutionaliserede dominerende udgaver af islam, der klart lægger afstand til de dele, der er uforenelige med demokrati, frihed og ligestilling.

Der findes stort set ingen religiøse ledere med vægt og anseelse, der åbent siger det nødvendige: At muslimer ikke er forpligtet på de religiøse love, ikke skal drømme om et religiøst samfund, ikke er overordnet andre religioner, og at islams påstand om tekstens og profetens totale ufejlbarlighed og deraf følgende fortrængning af fri tænkning er dybt skadelig og må forandres.

Bedst vil det naturligvis være, hvis forandringen kunne ske i god ro og orden. Hvis terrorister og voldsmænd virkelig er forkerte muslimer, må alle de rigtige muslimer jo tage ansvaret for at lade deres religion gennemstråle af oplysning og sekularisering. Problemet er blot, at det har lange udsigter, og hvis denne proces allerede er i gang, må man sige: Det bliver en lang og blodig affære, en historisk værdikamp mellem sekulær frihed og religiøs totalitarisme.

Her skal de vestlige samfund forsvare sig. Myndighederne skal konfrontere og bekæmpe kravet om eksklusivitet fra statens love og samfundets normer.
Staten skal gå langt for at kontrollere og overvåge de kræfter, der er parate til at dræbe civile på enhver given dag overalt i Europa. Politikerne skal naturligvis også tage det dybt seriøst, at så mange europæiske muslimer finder en stærkere identitet $\mathrm{i}$ islam, og bekæmpe de årsager, der kan findes til det. Tilbage står, at der stadig vil være mange muslimer, unge og gamle, mange af dem født i Europa, som bekender sig til en religion, som ikke bare står i modsætning til de samfund, vi ønsker, men danner en ring omkring dem af deres trosfæller, der er parate til at slå børn i Manchester og unge i London ihjel for at udbrede den sande tro. Mange insisterer på, at vi derfor, i det sekulære, gudløse Europa, selv skal finde tilbage til religiøse værdier og tankesæt for at kunne bekæmpe det. Det vil være helt forkert.

Det, der har gjort vores samfund frie, åbne og demokratiske, er ikke religion, men oplysningens krav om at sætte mennesket frit. Frit til at tænke, tale og leve. Heri ligger nogle meget hårde principper, der skal håndhæves dagligt.

Det er dét, vi skal insistere på - over for alle, der lever i vores del af verden.

\section{Anden akt:: Er islam ufredens religion? \\ (Jakob Skovgaard-Petersens indloeg på Facebook) \\ Martin Krasnik har skrevet en leder i Weekendavisen om 'ufredens religion,} hvormed han mener islam. Der står mange fornuftige ting; han slår fast, at alle religioner har en voldhistorie og et voldspotentiale, men at det i dag er islamisk vold, der er truslen, også imod muslimer. $\mathrm{Og}$ at det er afgørende vigtigt at nedkæmpe og imødegå voldelige islamiske ideologier og bevægelser, ligesom at det er komplet uacceptabelt, at der i Europa er muslimer, der sympatiserer med deres terror imod civile. 
Alligevel er jeg uenig i Krasniks overordnede argumentation, som altså går på, at islam som sådan er ufredens religion. At mene andet, siger han, er 'ønsketænkning' og udtryk for at 'sund fornuft og dømmekraft kortsluttes', når vi diskuterer religion.

Krasnik opponerer imod, at muslimske ledere og andre muslimer kalder islam for 'fredens religion' - nu der begås så mange voldelige uhyrligheder i islams navn: "jo oftere uskyldige civile dræbes med henvisning til islam, islamiske dogmer og islamiske tekster, desto mere afvises det, at religionen har noget med sagen at gøre".

Det er, i mine øjne, netop hvad disse millioner af muslimer og deres ledere skal gøre. Det er en islamisk formulering af den afstandtagen, vi så gerne ser. $\mathrm{Og}$ det er et led i en intern kamp mellem muslimer om at repræsentere sand islam. Det er ikke, fordi disse fredselskende muslimer nægter at se den virkelighed i øjnene, at terroristerne påberåber sig islam - det ved de udmærket godt finder sted. Det er fordi de nægter at lade terroristernes islam være deres. Det er ikke virkelighedsfornægtelse, men terrorfordømmelse. Det er i virkeligheden også sådan, Obama brugte det; igen var han jo helt klar over truslen fra jihadisterne, og beordrede selv droneangreb, mord på ledende jihadister osv. Så selvfølgelig var der ikke tale om, at Obama var naiv, men om at han kom med et vigtigt politisk udsagn, henvendt til muslimer i USA og andre steder, om at han ikke tog jihadisternes version af islam som den rigtige.

$\mathrm{Vi}$ andre - forskere og redaktører fx skal derimod ikke sige, det er den forkerte heller. Det er ikke vores opgave at fastslå, at islam er fredelig eller voldelig, men vi skal konstatere, at sådanne modsatrettede tolkninger af islam hver har deres for- talere blandt muslimer, og hver med deres argumenter, fra skriften, historien og andre steder. Vi må erkende og agere på, at jihadister (terrorister med en specifik islamisk begrundelse for deres vold) findes og truer os. Vi må undersøge deres handlinger, rekruttering og ideologi, og hvordan de kan imødegås - herunder muslimske argumenter og strategier. Men vi skal naturligvis ikke kanonisere jihadisternes udlægning af islam som den rigtige.

Det er bare det, Krasnik kommer til, når man omvendt de-legitimerer de muslimer, der afviser, at det har noget med islam at gøre. Han forklarer i virkeligheden, at jihadisterne følger det, der står i de muslimske autoritative skrifter, mens deres modstandere ikke gør det, eller gør det mindre. Jihadisterne er de rene og konsekvente muslimer. For Krasnik ved, hvad 'islam påstår' og hvad 'islam mener.' Han har åbenbart interviewet islam.

Jeg er med på, at særligt muslimske ledere gerne må gå i offensiven og detaljeret og konkret forklare, hvor og hvordan jihadisterne fortolker islam forkert. Det sker også. Men der måtte gerne være mere af det. Jeg er også med på, at mange ting er grundigt gale i den muslimske verden. Men at skyde skylden på islam for alle disse dårligdomme er forfejlet. I det meste af nyere tid har krig og ufred drejet sig om andre ting end religion: kolonialisme, Israel, kold krig, nationalistiske og socialistiske ideologier. Islam var som sådan ikke en central faktor. Selv om der er forløbere, er jihadismen som fuldt udviklet ideologi et produkt af afkoloniseringen, og egentligt jihadistiske grupper træder først frem på scenen i 1970’erne. I det 20 århundrede opstår der også andre, i perioder ret toneangivende, tolkninger af islam, herunder at den er 'fredens religion'. Den sekulariserede 'westfalske' ide om, at verden 
består af stater, som kan have en religiøs identitet, men alligevel leve med hinanden i fred, er faktisk også blevet normen i den muslimske verden, og fremmet af muslimske lærde, selv om man mente noget andet i middelalderen.

Disse krigeriske og fredelige tolkninger er historiske og vil blive forandret. De er kort sagt ikke noget, 'islam påstår,' men noget som nogle lærde, magtfulde eller jævne muslimer påstår, at islam påstår. For os, der har studeret de her ting $i$ årtier, er det udviklingerne i muslimernes trosopfattelser og verdenssyn, der er så slående. Ligesom i øvrigt i andre religioner. Igennem det seneste hundrede år har muslimer i Muhammad set en krigsherre og en fredsfyrste, en kapitalist og en socialist.

Det er i den forbindelse vigtigt også at gøre op med Krasniks opfattelse af sekularisering som noget uafvendeligt og godt, samt at den muslimske verden lever i en slags præ-oplysningstid. Det er ikke tilfældet. Den lever i vores samtid. Og ligesom i jødedommen og kristendommen har der været og er fremdeles væsentlige nytolkninger af islam, ofte inspireret af normer og værdier, som muslimer deler med deres ikke-muslimske samtid. På godt og ondt. For det går ikke nødvendigvis mod det bedre.

Krasnik synes at mene, at nogle religioner for altid er kommet home free takket være 'sekularisering og oplysning.' Men mange af de mest barbariske udviklinger i religionerne har fundet sted som en respons på sekularisering og oplysning, ikke før. De største massakrer i menneskehedens historie fandt sted i det 20. århundrede, og det var kun i mindre omfang muslimer og i større omfang katolikker, protestanter, ateister og andre, der begik dem. En ædruelig sammenligning af Ve- stens og den islamiske verdens historie vil ikke simpelthen vise 'fredens religion' i vest og 'ufredens religion' i øst.

Så rimelig Krasnik umiddelbart kan lyde, rummer hans tekst derfor ingen løsninger, men røber i stedet nogle af problemerne ved det dominerende tankesæt i den danske debat: nemlig at islam er et 'altomfattende system' som 'både er stat og religion', nedfældet i deres grundskrift, som determinerer muslimernes handlinger. Og at ingen muslim - læg eller lærd har turdet gøre op med dette system.

Endelig er det en skam, at en så fornuftig og redelig mand som Martin Krasnik indirekte siger, at det at benægte, at islam som sådan er ufredens religion, er lig med 'ønsketænkning' og kortsluttet dømmekraft. Hvorfor er det så vigtigt for ham, at vi ikke skal koncentrere os om de muslimer, der vitterligt er krigeriske og voldelige (og andre som er sexistiske, chauvinistiske og bigotte), men derimod 'islam' selv - et islam, som 'mener' og 'påstår' noget ganske specifikt?

Og hvorfor skal vi, der ikke er enige millioner af muslimer og næsten alle seriøse ikke-muslimske forskere - fratages fornuft og dømmekraft? Det lyder som nogle af de evige islam-debattører, der skjuler, hvor dårligt belagt deres islamanalyser er, ved at pynte dem med, at de er 'politisk ukorrekte' - som om denne grandstanding i sig selv gør dem mere rigtige. Sagen er, at ingen islamforsker benægter, at jihadisme har noget med islam at gøre - selv har jeg skrevet om jihadistiske islamtolkninger i henved 30 år - men det er den slags, vi får skudt i skoene af de mest anti-muslimske bloggere. Men for os er det ikke et skridt frem at diskutere, om islam selv er voldelig. Det er et skridt tilbage. Fordi det endnu engang fjerner fokus fra solide undersøgelser af 
vores egentlige objekt: muslimer. Hvorfor den muslimske verden står, hvor den står, hvad muslimske teologer og lægmænd diskuterer, hvorfor jihadismen blomstrede op, og hvor jihadisterne og deres mange muslimske modstandere er på vej hen. Men det er også et skridt tilbage i den forstand, at postulatet om islam som ufredens religion giver jihadisternes tolkning alt for megen kredit.

\section{Tredje akt: Tekst fra den helt uvidende, fordomsfulde islamhader}

(Martin Krasniks svar til Jakob SkovgaardPetersen, skrevet specielt til Udenrigs) Jakob Skovgaard-Petersen er en af vores dygtigste islamforskere. Det er jeg ikke. Men jeg ved, hvad jeg selv mener, så jeg kan med stor autoritet sige, at han læser min leder, som fanden læser Koranen.

Nej, jeg mener ikke, at islam forklarer alle dårligdomme i den muslimske verden. Naturligvis ikke. Jeg mener heller ikke, at jihadisternes fortolkning af islam er den 'eneste rigtige', og at alle andre dermed tager fejl. Naturligvis ikke. Jeg er også helt enig $i$, at der er forskellige tolkninger af islam. Jamen, selvfølgelig, hvad ellers? Jakob Skovgaard-Pedersen gør det alt for nemt for sig selv ved at lade, som om jeg ignorerer åbenlyse sandheder. Han tegner et billede af alle andre end dem, der har studeret islam i årtier og taler arabisk, som uvidende fjolser.

Lad mig være meget konkret: Store flertal i alle muslimske lande ønsker, at sharia-lovgivning står over demokratisk indførte love. Jo mere religiøse muslimer er, desto mere ønsker de religiøs lovgivning. Der er enorm modstand mod homoseksualitet, religiøs pluralisme, kvinders rettigheder, ytringsfrihed og andre demokratiske friheder og rettigheder. Hvorfor? Og hvorfor er samme holdninger så udbredt blandt muslimer i Vesten. Hvorfor går integrationen så trægt? Jeg vil så gerne høre islamforskernes svar.

Jeg er helt med på, at der er mange andre forklaringer også, islamisme som reaktion på afkoloniseringen, modstand mod Israel, ikke mindst den vestlige alliance med landet, socioøkonomiske forklaringer osv. Men hvordan bidrager islamiske dogmer, islamisk teologi og de udbredte, institutionaliserede fortolkninger af islamiske tekster? Betyder det slet ikke noget, at islam er en lovreligion med regler og anvisninger for, hvordan både den enkelte muslim skal leve, og hvordan man skal leve sammen i et samfund?

Jeg mener, som jeg skrev, heller ikke, at andre religioner er uproblematiske. Det historiske og teologisk institutionaliserede kristne jødehad spillede en vigtig rolle i Holocaust. Jeg er selv vokset op med jødedommen - ligesom islam en lovreligion med ortodokse krav om at indehave den sande, bogstavelige version. Men hvorfor ønsker et flertal af jøderne alligevel ikke religiøs lovgivning? Måske fordi jødedommen har været igennem en meget stærk oplysningsperiode (Haskalah), hvor stærke religiøse tænkere arbejdede for kulturel og religiøs fornyelse, integration af jøder i de omgivende samfund og en moderne, kritisk tilgang til teologi og tekst. Resultatet er, at der er totalt genneminstitutionaliserede liberale og reformerte retninger, hvor man sagtens kan være meget troende uden at tage teksterne og dogmerne bogstaveligt. Eller fuldkommen ateist uden at blive opfattet som frafalden. Eller lesbisk rabbiner med en stor menighed i ryggen. Det skyldes ikke mindst, at jøder har levet som minoriteter i århundreder, men det skyldes også, tror jeg, at Det Gamle Testamentes Gud er en patriarkalsk undertrykker og tyran, men også en Gud, som 
man dybt i teksterne konstant diskuterer og kværulerer med. Det forekommer mig, at muslimerne omgås deres gud og profet med en noget anden varsomhed.

Jakob Skovgaard-Petersen skriver, at islam har haft sin oplysningstid og reformation. Ja, naturligvis har der været reform-tænkere, der ønskede et mere oplyst islam. Men hvorfor har de ikke haft større gennemslagskraft? Kunne det have noget at gøre med islamisk dogmatik? Skovgaard-Petersen er trods alt ikke den eneste islamforsker i verden. Andre er uenige med ham. Uden at tale om en uforanderlig essens i islam mener væsentlige forskere, at islam af forskellige grunde, der selvfølgelig har med religionen at gøre, er nemmere at mobilisere til vold, kamp og konflikt.

I stedet for at feje denne diskussion ind under gulvtæppet og beskylde dem, der tager den op, for at gøre problemerne værre, burde Skovgaard-Petersen med sin store viden hellere bidrage til at give debatten mere substans.

\section{Fjerde akt: Er islam ufredens religion} (2)?

(Jakob Skovgaard-Petersens svar til Martin Krasnik, skrevet specielt til Udenrigs) Hvad betyder en overskrift som 'Ufredens religion'? Ifølge Martin Krasnik er langt hovedparten af verdens muslimer fredsommelige; og ufredelige tekststeder og mennesker findes også i andre religioner. Men hvorfor vil han så titulere islam på den måde? Det forstår jeg stadigvæk ikke. For det har da oplagte konsekvenser at gøre det.

De punkter i Krasniks leder, som jeg tog op og kritiserede, har han nu forladt: væk er påstanden om at vide hvad 'islam siger', væk er kritikken af de muslimer, der opfatter islam som fredens religion. Væk er i det hele taget terror, vold og ufred som noget, der nødvendigvis hører islam til. Det er jeg glad for. Så lad mig bruge pladsen til at forklare noget om religion og lov generelt og sharia specifikt.

I stedet for at tale autoritativt om islams lære optræder Krasnik denne gang som den, der kan se, at der er noget galt mange steder i den muslimske verden. Det kan vi andre også. Han introducerer en række nye emner: modstand mod homoseksualitet, religiøs pluralisme, kvinders rettigheder, ytringsfrihed og andre demokratiske friheder og rettigheder. Det er jo også vigtige emner - blot noget andet end ufred. Og det er jo sandt, at mange muslimer har holdninger til de emner, der støder imod vore egne. Det er der i øvrigt også mange kristne rundt omkring i verden, der har. Ligesom de fleste af vore tipoldeforældre havde fordømmende holdninger til homoseksualitet eller kvinders ligeberettigelse, eller religiøs pluralisme som vi forstår det i dag. Holdninger, som de også dengang begrundede med religiøse argumenter og referencer. Uden at man dengang eller i dag kalder deres religion for ufredens. Ironisk nok var den muslimske verden tidligere mere afslappet end Europa, når det kom til homoerotik eller tolerance over for anderledes troende og tænkende.

Det er den ikke i dag. Jeg nævner det derfor heller ikke for at benægte, at den slags holdninger er mere udbredte i den muslimske verden end de fleste andre steder, men for at sætte dem i en bredere historisk kontekst. Og derved påpege, at bestemte holdninger til disse spørgsmål ikke er determineret af religion, og at religiøse mennesker har fundet legitimering for forskelligartede, ja modsatrettede, synspunkter i deres tradition.

Det er den religiøse determinisme, jeg opponerer imod, altså forklaringer på nu- 
tidige sociale fænomener med henvisning til skriftsteder eller dogmer. Teologocentrisme, kalder nogle det. Den form for forklaring dominerede i moderniseringsteorien, en bestemt meget håndfast læsning af Max Weber i 1950'erne, hvor man vurderede forskellige landes og religioners udviklingspotentiale. For eksempel om katolske lande kunne blive demokratiske, når de nu havde en så hierarkisk og autoritativ kirke, eller om muslimer nemmere ville falde for kommunismen, fordi deres religion var så egalitær: kunne 'broder' blive til 'kammerat'?

Mange af disse idéer om religiøse værdiers forhindring af demokrati eller liberalisme blev indhentet af virkeligheden. Videnskab drejer sig også om at falsificere; så hvis man eksempelvis mener, at volden skyldes islam, er man nødsaget til at forklare, hvorfor så mange muslimer ikke er voldelige. Og hvis kristendommen ikke er en voldsfremmende religion, bliver man vel også nødt til at forklare, hvorfor kristne har begået så exceptionelt megen vold $i$ historien. Det var den slags problemer, der fik forskere til at omtænke deres kategorier, og som førte teologocentrismen i miskredit.

For der er alt muligt andet end religion, der influerer kultur og samfund, og det er $i$ langt højere grad tidens normer og opfattelser, der præger forståelsen af religionen, end det er religionen, der former tiden - især i moderne tid; i hver generation har religiøse mennesker fundet sandheder i deres tekster, som bekræftede deres identitet, værdier og verdensforståelse. Krasnik leverer et udmærket eksempel selv, når han mener, at jødedommen altid har været præget af, at israelitterne trodsigt diskuterede med Gud selv. Det er en smuk og humanistisk udlægning af jødedommen. Men uden at være sagkyndig tvivler jeg på, at man vil finde den fortolkning af jødedommen i jødiske tekster før det 20 århundrede, og jeg tror ikke, at den var et afgørende argument i den jødiske emancipation og reformisme.

Krasniks beskrivelse af jødedommen som oplyst og pluralistisk forbigår, at der desværre også er illiberale, chauvinistiske og somme tider voldelige jødiske grupper, hvis rolle i Israel har været voksende i årtier. Hverken i det jødiske eller i det islamiske tilfælde drejer det sig om små enklaver af troende, der ikke har været eksponeret til oplysningens klare lys. Det er folk, der reagerer imod den. Krasnik siger, at den islamiske reformation ikke har haft gennemslagskraft. Det argument ville man så også kunne anvende om den jødiske. Men det ville være forkert. For fundamentalistiske tolkninger af religionerne er på mange interessante måder et vidnesbyrd, ikke om reformationernes fiasko, men om deres succes.

Israel er præget af en voldsom kulturkamp om disse emner. Det er de muslimske samfund også. Men her gør Krasnik kampen til noget nær afgjort på forhånd; nu ikke længere ved at vide, hvad 'islam siger', men med henvisninger til 'noget' i islamisk tradition eller 'sharia'. Her skulle han ikke være så sikker. Islam og jødedommen ligner hinanden ganske meget, både hvad angår lovens indhold og dens forvaltning, med skoledannelser, pluralisme og argumentationsmåder. Jeg har været til konferencer om islamisk og jødisk lov, hvor rabbinere og sheiker sammen godtede sig over lighederne i de forskellige sindrige teknikker, som disse traditioner har anvendt til at fortolke loven på fleksible måder. En genoplivelse af traditionens fleksibilitet og spiritualitet er faktisk en af en række strategier i den ovennævnte kulturkamp. Hvis der i dag er flere 
jøder end muslimer, der har liberale tolkninger af deres religion, hænger det næppe sammen med en forskellig 'grundsubstans', men langt mere med de generelle omstændigheder, de lever under i dag.

Det har fået mig til at tænke på religion og lov på en meget anden måde, end Krasnik gør. Som Durkheim påpegede, har alle religioner til opgave at sanktionere samfundets love og normer, og i den grundlæggende forstand er de alle lovreligioner. Både jøder og muslimer, og tidligere kristne, har haft en lov, som styrede deres samfundsliv. I dag har de måttet tilpasse den en statslov, hvor de end bor. Men staterne har omvendt også trukket på de religiøse love, og de religiøse love lever videre i personlig livsførelse og etik.

Når Krasnik siger, at store flertal af muslimer vil have indført sharia, så siger de samme store undersøgelser fra Pew og Gallup, at store flertal af muslimer også vil leve i demokratier. De muslimer ser altså ikke nødvendigvis den samme modsætning mellem sharia og demokrati, som Krasnik tager for givet. Det burde lede os til mere indgående at undersøge begrebet sharia - et begreb som danske politikere og debattører elsker at tale om, men som de synes at have ret uklare idéer om.

Det er ikke så sært. For det har mange muslimer også, og sharia fortolkes vidt forskelligt. Sharia er nemlig ikke en enkelt bog eller en enkel lære, men en mangeartet tradition, baseret på tekster, som ofte modsiger hinanden. Når de så alligevel følger sig så knyttet til sharia, er at det ikke mindst fordi sharia ikke primært er lov i vores betydning, men også udførelsen af de muslimske pligter og ritualer, foruden samfundssind og etik - omtrent, faktisk, som jødisk lov, halakha.

Sharia betyder Guds vej, den åbenbarede lov. En sådan lov havde jøderne og de kristne også, og ældre muslimske tekster taler da også om jødernes og de kristnes sharia. Man vil derfor se mange muslimer, der vil hæge om sharia, men ikke ser det som et problem at leve i et demokratisk land som USA eller Danmark, så længe de føler, de kan praktisere deres grundlæggende religiøse pligter. Da Krasnik for nogle år siden forsvarede traditionen med mandlig omskæring, må mange muslimer have følt, at han forsvarede sharia, mens jøder følte han forsvarede halakha, og en del øvrige borgere som jeg selv fandt, at han forsvarede Danmarks traditionelle religiøse liberalitet.

Også i de lande, hvor muslimer er en majoritet, er der i dag en statslig lov, som indbyggerne skal følge, uanset om de mener, at den stemmer overens med sharia. Nogle, men langt fra alle, muslimske stater siger i deres forfatning, at deres lovgivning bygger på sharia. Alligevel har de vidt forskellige institutionelle, juridiske og $ø$ konomiske politikker. Og der er ganske stor forskel på, hvordan de øverste religiøse autoriteter i Saudi-Arabien, Marokko, Tyrkiet, Iran, Egypten eller Indonesien udlægger sharia.

Mange muslimer i de lande er kritiske både over for disse autoriteter og over for selve politiseringen af sharia i statslig lovgivning - men en stor del også af denne gruppe opfatter alligevel sharia som relevant i deres eget liv. Selv den gruppe af muslimer, der gerne ser sharia influere statens politik - dem vi kalder islamister kan mene meget forskelligt: De har ingen pave til at docere det fra sin lærestol. For nogle er det den klassiske juridiske litteratur; for andre er det reformisternes modernistiske tolkninger centreret om, hvad der er i ummaens interesse. Hvilket igen kan tolkes i både liberale og illiberale retninger. Salafister mener, at de gennem 
studier af hadith kan rekonstruere loven, som Muhammad forstod den. Så vi bliver nødt til at fastslå, hvad der egentlig menes i den konkrete situation, når muslimer siger sharia, hvad enten de er islamister eller ej. Det kan variere fra noget, der er ret så pragmatisk eller spirituelt, til noget der er voldsomt rigidt og brutalt.

Det gælder også deres opfattelse af demokrati. Radikale islamister har siden 1950'erne hævdet, at demokrati er u-islamisk, fordi kun Gud er lovgiver. Andre islamister har set mere positivt på demokrati, og nogle er ligefrem begyndt at opfatte demokrati som en islamisk styreform, med forløbere i tidlig islam. De ser netop den politiske orden som noget, Gud har overdraget til mennesket og dets fornuft. Islamistiske bevægelser og deres ideologer argumenterede i 1950'erne stærkt imod idéen om folkesuverænitet eller kvindelig valgret og valgbarhed. Det har de helt forladt. Sådanne udviklinger opfanger man ikke, hvis man holder sig til, hvad man mener, at islam eller sharia docerer.

Krasnik antyder, at forskere som mig skyer bort fra de islamiske dimensioner af nutidig politisk og social handlen. Men det er faktisk netop mit felt. Jeg undersøger, hvordan vigtige muslimske tænkere, teologer og institutioner anvender islamiske tekststeder, traditioner og begreber, og hvordan dette indhold har udviklet sig over tid. Så når Martin Krasnik opfordrer mig til at give debatten substans, må jeg henvise til, hvad jeg har skrevet - på dansk fx i bogen Moderne islam, som altså netop tager religionen alvorligt, men som noget muslimer slås med, og ikke som noget de er dikteret af. Det er en tekstantologi, som viser, hvordan centrale teologiske og juridiske opfattelser har ændret sig i moderne tid. Det gælder ikke mindst på de områder, Krasnik opfatter som resultater af en uforanderlig islamisk lære.

Hvorfor ændrer de sig så? Fordi verden ændrer sig, og muslimerne og vi andre med den. Det er ikke en interesse- eller magtfri erkendelsesproces, og den går ikke altid mod det bedre. Men den bevæger sig. Selv dér, hvor samfundets kulturelle og religiøse værdier synes at være traditionelle eller uforanderlige. Dette opgør med teologocentrismen er godt formuleret af Barrington-Moore i The Social Origins of Dictatorship and Democracy (1967):

"Kultur eller tradition er ikke noget, der eksisterer uden for eller uafhængigt af de individuelle mennesker, som lever sammen i samfundet. Kulturelle værdier kommer ikke ned fra himlen for at influere historiens forløb. At forklare en bestemt handling med henvisning til kulturelle værdier er at foretage en cirkelslutning. Formodningen om inerti, at kulturel og social kontinuitet ikke kræver en forklaring, er ensbetydende med at overse den kendsgerning, at begge dele må skabes på ny $i$ hver eneste generation, ofte med stor smerte og lidelse. Med det formål at opretholde et værdisystem bliver mennesker slået, hundset, smidt i fængsel, sendt i koncentrationslejr, besnakket, bestukket, gjort til helte, opmuntret til at læse aviser, stillet op ad en mur og skudt, og sommetider endda undervist i sociologi. At tale om kulturel inerti vil sige, at man overser de konkrete interesser og privilegier, som har fordel af indoktrinering, undervisning og hele den komplicerede proces, det er at overføre kultur fra en generation til den næste."

Denne opfattelse af kultur og religion flytter fokus fra tekst og tradition til fortolkning og institution - den vinkel jeg har arbejdet med i mange år. Det er klassisk empirisk religionsforskning og noget 
ganske andet end socialkonstruktivisme. I forhold til sin leder er Krasnik nu i sin replik til mig på vej derhen, og det er glædeligt. Det bør betyde, at han ikke ser muslimer som produkter af en tradition, men som en ny generation af forvaltere og fortolkere af den; måske influeret af tidligere tolkninger - som kommer i en rig variation - men somme tid i bevidst brud med dem, og under alle omstændigheder ikke simpelthen determineret af dem. Det bør betyde, at han anerkender, at ingen i denne ny generation fornægter den virkelighed, at jihadister påstår at være (de eneste) sande muslimer, men at de for langt størstedelen er lodret uenige i denne påstand. Og det bør betyde, at han støtter dem i deres afstandtagen i stedet for at mistænkeliggøre dem.

Det er der nemlig andre, der gør. De opfattelser, som Krasnik i sit svar afviser som selvfølgeligt forkerte, er nemlig ved at være ganske udbredte i Danmark: at islam som sådan er inkompatibel med demokrati og liberalisme; at islam som sådan er den primære eller ligefrem eneste grund til elendigheden i Mellemøsten; at jihadisterne repræsenterer islams sande lære; at man er islamist, hvis man ikke vil afsværge sharia. Når nu Krasnik også mener, at det er helt hen i vejret, synes jeg, at han som redaktør og lederskribent skulle bruge en hel del kræfter på at fastslå de selvfølgeligheder. Lederen om 'Ufredens religion’ trækker desværre i den modsatte retning.
Martin Krasnik er en dygtig journalist og sikkert bedre begavet end mig. Jeg har ikke kaldt ham et fjols eller bebrejdet ham, at han ikke kan arabisk. Han roser mig som forsker og opfordrer mig til at give debatten mere substans. Det vil jeg gerne, men så må han jo også lytte til, hvad jeg siger. Mine studier i moderne islam leder mig altså til at sige, at Krasnik i dette tilfælde har stillet de forkerte spørgsmål og under en generaliserende og vildledende overskrift. Og her repræsenterer jeg ikke en slags fløj i islamforskningen. Jeg kender ingen topforsker i moderne islamiske studier, der ville karakterisere islam som 'ufredens religion' som sådan. De franske forskere - Roy, Kepel og Burgat som Weekendavisen har bragt frem i nogle ret mystiske kommentarer til mit opslag, vil i hvert fald ikke. Krasnik siger, at de findes. Jeg tager gerne debatten, når de dukker op.

Det er af mange grunde vigtigt, hvordan vi opfatter islam, og hvad vi kalder den ikke mindst i vore bestræbelser for at bekæmpe jihadismen. For vi skal stå skulder ved skulder med muslimerne i denne kamp - som ikke mindst er deres. I den forbindelse er det opmuntrende, at så mange unge danske muslimer - religiøse som ikke-religiøse - har delt mit svar til Krasnik til forsvar for de muslimer, der opfatter islam som fredelig. 